\title{
Under the Shadow of China.
}

Beijing's policy towards Hong Kong and Taiwan in comparative perspective.

\section{Samson Yuen}

\section{(2) OpenEdition \\ Journals}

Electronic version

URL: http://journals.openedition.org/chinaperspectives/6491

DOI: 10.4000/chinaperspectives.6491

ISSN: 1996-4617

\section{Publisher}

Centre d'étude français sur la Chine contemporaine

\section{Printed version}

Date of publication: 1 June 2014

Number of pages: $69-76$

ISSN: 2070-3449

\section{Electronic reference}

Samson Yuen, « Under the Shadow of China. », China Perspectives [Online], 2014/2 | 2014, Online since 01 January 2017, connection on 15 September 2020. URL : http://journals.openedition.org/ chinaperspectives/6491 


\title{
CefC News Analysis
}

\section{Under the Shadow of China}

\section{Beijing's policy towards Hong Kong and Taiwan in comparative perspective}

\author{
SAMSON YUEN
}

$\mathrm{O}$ n 18 March 2014, student protesters stormed Taiwan's Legislative Yuan, kicking off to a 24-day sit-in that paralysed the island's legislature. The historic occupation, later given the name Sunflower Student Movement (taiyanghua xueyun 太陽花學運), was a protest against the attempt by the ruling Kuomintang (KMT) to pass a service trade pact with China. The pact, entitled the Cross-Strait Service Trade Agreement (CSSTA), (1) was signed between China and Taiwan in June 2013 as one of two follow-up treaties to the Economic Cooperation Framework Agreement (ECFA) signed in 2010. (2) As a component of ECFA, CSSTA vows to substantially liberalise trade in services between the two economies. Up to $80 \mathrm{Chi}$ nese industries and 64 Taiwanese industries will be opened up under the pending agreement.

Apart from the extraordinary vibrancy of Taiwan's civil society participation, another distinctive feature of the Sunflower Student Movement was the constant reference to Hong Kong in the protest rhetoric. The service trade pact in question, together with its parent treaty ECFA, was widely thought to be a replica of the free trade agreement signed between Hong Kong and China in June 2003, named the Mainland and Hong Kong Closer Economic Partnership Arrangement (CEPA), and framed at that time as a "generous gift" from Beijing to pull Hong Kong out of its economic low-tide brought by the SARS epidemic. (3) While CEPA, after over a decade of implementation, has significantly increased cross-border economic cooperation as intended and, perhaps more arguably, has achieved considerable economic results as claimed by the government and some mainland scholars, ${ }^{(4)}$ it has certainly made the Hong Kong economy more dependent on China and, more crucially, has created an open platform for China's United Front strategy to co-opt local economic elites. ECFA was thus seen by observers as an agreement broadly modelled upon Hong Kong's CEPA, as both of them contain the objective of increasing cross-strait economic integration ${ }^{(5)}$ - just as it is often pointed out that Hong Kong's "One Country Two Systems" was originally devised by Deng Xiaoping as a formula ultimately aimed at the reunification of Taiwan with China. ${ }^{(6)}$ Chinese officials even explicitly proposed the concept of a "Greater China Economic Circle" (dazhonghua jingji quan 大中 華經濟圈) through which economic cooperation between Hong Kong, Taiwan, and China can be fostered through ECFA and CEPA. (7) Both pacts, as clearly stated, aim to normalise and facilitate inter-and-cross-territory trade relations in goods, services, and investment. Less explicitly revealed, however, is the parallel objective, which has been pointed out by observers in Hong Kong and Taiwan, to induce political integration through closer economic partnership with China.
With the lessons of CEPA in mind, opinion in Taiwan was divided over the service trade pact. Supporters, including the KMT government led by President Ma Ying-jeou, argued that the pact would be economically beneficial to Taiwan while diplomatically indispensable for Taiwan to join other free trade zones such as the Regional Comprehensive Economic Partnership (RCEP) and the Trans-Pacific Partnership (TPP). ${ }^{(8)}$ Opponents argued that the pact lacked a democratic mandate and condemned the negotiation process between the CCP and KMT governments as a "black box" (heixiang 黑箱). Meanwhile, quoting a government report estimating that the trade pact would only boost GDP by $0.03 \%$, ${ }^{(9)}$ they argued that the economic benefits were not as clear as supporters claimed. Instead, they worried that opening Taiwan's service industry to Chinese companies would harm local small-business owners and create only low-skill service jobs, pointing to Hong Kong's widening poverty gap after the implementation of CEPA. (10) Beneath these reservations, however, lies a deeper existential concern. Pro-

1. The Cross-Strait Service Trade Agreement (Chinese version) is available at www.ecfa.org.tw/SerciveTradeAgreement1.aspx?pid=7\&cid=26\&pageid=0 (accessed on 22 April 2014).

2. Official translation of the Cross-Straits Economic Cooperation Framework Agreement, available at www.ecfa.org.tw/EcfaAttachment/ECFADoc/ECFA.pdf (accessed on 22 April 2014).

3. The legal text of CEPA and its supplements are available at www.tid.gov.hk/english/cepa/ (accessed on 22 April 2014).

4. "Happy economic returns after 10 years of CEPA (with photos)," Hong Kong Government, 2 September 2013, available at www.info.gov.hk/gia/general/201309/02/P201309020603.htm (accessed on 22 April 2014); The Trade and Industry Department of Hong Kong publishes its own studies on CEPA's impact on the economy, which are available at www.tid.gov.hk/english/cepa/ statistics/statistics_research.html (accessed on 22 April 2014); Yun-yuan Zhou, Quyu yitihua:Xianggang zai fan zhusanjiao de zuoyong yanjiu (Regional Integration:The Function of Hong Kong in the Pearl River Delta), Social Science Academic Press, August 2009.

5. Yun-wing Sung, "A comparison between the CEPA and the ECFA," in Peter C.Y.Chow (ed), Economic Integration Across the Taiwan Strait: Global Perspectives, Cheltenham, UK, Edward Elgar Pub, January 2013; Vincent Y. Chao, "ECFA panders to large corporations at expense of small companies, DPP says," Taipei Times, June 25, 2010; "Zhuanjia: ECFA yu CEPA mubiao fangxiang yizhi" (Expert: ECFA and CEPA have the same objective and direction), Wenweipo, 30 June 2010, available at http://paper.wenweipo.com/2010/06/30/CH1006300011.htm (accessed on 22 April 2014).

6. Ho-fung Hung and Huei-ying Kuo, ''One Country, Two Systems' and Its Antagonists in Tibet and Taiwan," China Information, Vol. 24, No. 3, 2010.

7. "Chang liangan sandi gonggou dazhonghua jingjiquan" (Proposing to build a Greater China Economic Zone between Hong Kong, Taiwan and China), Now News, 30 April 2013, available at www.nownews.com/n/2013/04/30/273748 (accessed on 22 April 2014).

8. Charles I-hsin Chen, "Sorry, the Protests Have Undermined Taiwan's Reputation," The Diplomat, 15 April 2014.

9. "Liangan fuwu maoyi xieyi jingji yingxiang pinggu baogao" (Assessment Report on the Economic Impact of CSSTA), Chung Hwa Institute for Economic Research, July 2013.

10. Xiu-ling Zheng, "Liangan fumao xieyi dui woguo de chongii fenxi" (The Impact of CSSTA on Taiwan), available at http://homepage.ntu.edu.tw/ ntuperc/conference-1-files/20130725_3_1.pdf (accessed on 22 April 2014); the Democratic Progressive Party made a TV commercial in 2010 comparing ECFA and CEPA, which argues that Hong Kong under CEPA has had one of the world's largest poverty gaps, available at www.youtube.com/watch?v=xn_UMtw3sSA (accessed on 23 April 2014). 
testers fear that the service trade pact will make the de facto independent Taiwan vulnerable to more direct forms of political intervention from Beijing, a constant threat that has pervaded Taiwanese society since the KMT retreated to the island in 1949. ${ }^{(11)}$ Meanwhile, Taiwan's service trade pact debate aroused anxiety among people in Hong Kong over the decade-long but little scrutinised CEPA. Observers are starting to be aware of the fact that CEPA could be a United Front tool that has progressively undermined the cherished "One Country Two Systems" (yiguo liangzhi - 國兩制) arrangement.

This article puts Hong Kong and Taiwan in comparative perspective, with the aim of examining the effect of China's growing centripetal political influence on both territories. Despite considerable differences in their social and political history, Hong Kong and Taiwan have become increasingly similar over the past decade both in the way China seeks to exert political power on their domestic politics through playing the economic card, and in the way resistance against China's looming advance is shaped. This article reviews the arguments that compare the two territories. The first section looks at how both Taiwan's CSSTA/ECFA and Hong Kong's CEPA serve as tools of China's economic united front strategies. The second section highlights the convergence of Beijing's attitude towards Hong Kong and Taiwan as suggested by recent policy announcement. The third focuses on the political repercussions and how civil societies in both territories respond to Beijing's advances. As a result of China's converging policies towards the two territories, we are seeing more frequent exchanges between Hong Kong and Taiwan in recent years, and can expect to see more collaboration in the near future.

\section{Political integration through economic dependence}

Long insisting that Taiwan is an integral part of its territory, China has constantly attempted to exert influence on Taiwan politics to deter Taiwanese independence. During Taiwan's authoritarian era and the early years of democratisation, the perceived threat from China was sustained by the active threat of armed invasion. However, with China's "peaceful rise," Beijing's policy towards Taiwan gradually shifted from the reliance on military threat to paving conditions for "peaceful reunification" (heping tongyi 和平統一) through closer economic partnership. Starting in 2005, when Taiwan was still ruled by the pro-independence Democratic Progressive Party (DPP), China's former president $\mathrm{Hu}$ jintao increased contact with its erstwhile archenemy, the KMT, beginning with the historic meeting between $\mathrm{Hu}$ and thenKMT Chairman Lien Chan in April 2005. The meeting took place at a curious time because it was only a month after the ratification of China's Anti-Secession Law, which formalised "non-peaceful means" as an option of response to Taiwan's declaration of independence. ${ }^{12)}$ With the KMT winning the presidential election together with a legislative majority in 2008, Hu Jintao immediately adopted a softer approach towards Taiwan. In his six proposals for the peaceful development of cross-strait relations, Hu stressed "enhancing political mutual trust" under the "one-China principle," and vowed to advance economic cooperation between the two sides, hoping that the "normalisation of cross-straits economic relations" will "lay a more solid material foundation [...] for the peaceful development of cross-straits relations." "(13) Since then, cross-straits economic ties have steadily increased with the establishment of the three direct links of mail, transport, and business and the significant growth witnessed in Taiwan's trade volume and investment in relation to China. China is now Taiwan's biggest trading partner, representing more than $21 \%$ of total trade (40\% including Hong Kong), tripling the figure for 2002. ${ }^{(14)}$ Political contact also became more frequent. The Hu-Lien meeting in 2005 initiated the KMT-CCP Forum that hosted frequent party-to-party dialogues, and which, with the election of President Ma Ying-jeou in 2008, were transformed into semi-official government exchanges, leading to specific policies and agreements - most notably the ECFA and CSSTA. The softening of Beijing's approach towards the KMT was soon interpreted by the DPP camp and pro-independence commentators as the use of an economic United Front strategy to induce reunification with Taiwan. Most notably, Lin Chong-pin, former deputy defence minister of Taiwan, commented that Beijing had come to the realisation that it would be "cheaper to buy Taiwan than to attack Taiwan." (15)

How the KMT-CCP cooperation eroded Taiwan's democracy has been forcefully presented by André Beckershoff in a recent academic publication, (16) which also clearly described the political context for the recent protests against CSSTA. The article shows how the shift in cross-straits policy-making from a government to a party framework has brought about the formation of a powerful interest group bringing together KMT legislators, cabinet ministers, and business elites, who cannot be held accountable by democratic procedures. Consequently, one of the biggest anxieties towards signing the service trade pact is that the pact would facilitate China's United Front strategy and impact Taiwan's internal politics and national security. Seeing Beijing's persistent effort to co-opt Taiwanese elites, protesters fear that the service trade pact under ECFA will become an institutional platform to legitimate and normalise such ties. As Wu Jieh-min, a Taiwanese China scholar, observes, the CCP has been trying to build rapport with Taiwanese pro-unification politicians as well as business elites who have set up operations in China, forming networks that he called "cross-straits business and political alliances" (kua haixia zhengshang lianmeng 跨海峽政商聯盟), which act as a pivot for Beijing to leverage power in Taiwan's political terrain. ${ }^{(17)}$ Such networks, as explained by Wu, comprise big business conglomerates that have operational bases in both Taiwan and China, such as the Want Want Group, Ting Hsin Group, and Foxconn, which have great influence in Taiwan's political and business circles as well as on society. For example, the Want Want Group, after its massive expansion in China, returned to Taiwan and acquired the China Times Group in 2008, which included the island's influential newspaper China Times, China Television, Chung T'ien Television, and the Broadcasting Corporation of China. In 2011, it went on to acquire $60 \%$ of the second largest cable television services, previously owned by China Network Sys-

11. Richard Chiou-yuan Lu, "China, We Fear You," Foreign Policy, 21 March 2014, available at www.foreignpolicy.com/articles/2014/03/21/china_we_fear_you_taiwan_trade_pact_essay (accessed on 22 April 2014).

12. The full text of China's anti-secession law is available at http://english.peopledaily.com.cn/ 200503/14/eng20050314_176746.html (English) and http://news.xinhuanet.com/newscenter/ 2005-03/14/content_2694168.htm (Chinese).

13. Hu Jintao, "Let Us Join Hands to Promote the Peaceful Development of Cross-Straits Relations and Strive with a United Resolve for the Great Rejuvenation of the Chinese Nation," Speech at the Forum Marking the $30^{\text {th }}$ Anniversary of the Issuance of the Message to Compatriots in Taiwan, 31 December 2008, available at www.gwytb.gov.cn/en/Special/Hu/201103/t20110 322_1794707.htm (accessed on 29 April 2014).

14. Joshua Meltzer, "Taiwan's Economic Opportunities and Challenges and the Importance of the Trans-Pacific Partnership," Brookings East Asia Policy Paper Series, January 2014

15. "Sore points: How Taiwan and North Korea complicate the Sino-American relationship," Economist, 22 October 2009

16. André Beckershoff, "The KMT-CCP Forum: Securing Consent for Cross-Strait Rapprochement," Journal of Current Chinese Affairs, Vol. 43, No. 1, 2014, pp. 213-241.

17. "Interview: China influencing Taiwan via firms," Taipei Times, 26 January 2014, available at www.taipeitimes.com/News/taiwan/archives/2014/01/26/2003582181 (accessed on 22 April 2014). 


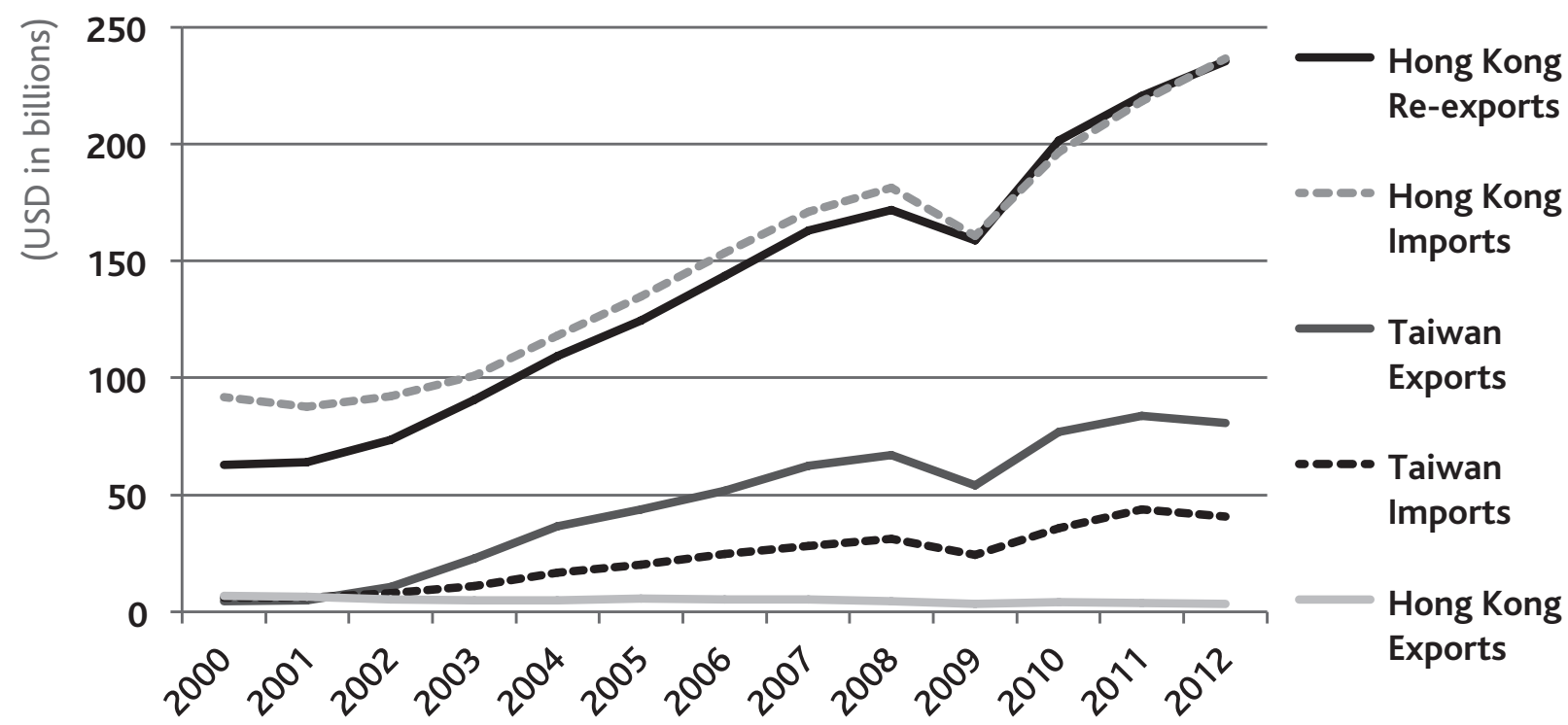

Source: Hong Kong Census and Statistics Department, Taiwan's Ministry of Finance.

tems. These acquisitions made the group the biggest media firm in Taiwan enabling it to influence public opinion - and, according to $\mathrm{Wu}$, also to "advocate Chinese nationalism" and "toe the same line as China's state-owned media." (18) In 2012, more than one hundred Taiwanese business leaders, including heads of these conglomerates, pledged support for the "1992 Consensus" (jiu'er gongshi 九二共識), which has been emphasised by Beijing as the "one China" principle, by placing ads in Taiwan's newspapers. However, it should be noted that the "1992 Consensus" ("One China, different interpretations") does not exist as such, as the CCP does not acknowledge the second part of the statement, while the KMT does not accept the first part without the second. Under Tsai Ing-wen, the DPP, which does not recognise the "1992 Consensus," advocated a new "Taiwan Consensus."

Another worry among protesters is that the trade pact will open the gate for the direct entry of Chinese capital. Opponents argue that this might harm the local economy, pose a threat to national security, and change Taiwan's way of life rather than making Taiwanese firms go global as claimed. As Wu notes, the promise of the trade pact to "globalise" Taiwan's economy is only a pretext to limit commercial activities to trade across the Taiwan Strait as opposed to opening up to the world, as business activities of Taiwanese "transnational corporations" only cover China and Taiwan. (19) Worse, as Taiwanese China expert Hsu Szu-chien suggested, the pact might even induce China to gradually bring state-owned enterprises to operate in Taiwan. Hsu predicted that these firms can first start small, and then quietly expand to monopolise Taiwanese industries with the backup of massive Chinese funds, so as to act as "tools of political dominance" in the long run. ${ }^{(20)}$ Some worry that the pact will open up Taiwan's strategic industries to Chinese companies, thus harming Taiwan's national interests. Rex How, a former advisor to President Ma and a veteran of Taiwan's publishing industry, pointed out that opening up the publishing industry, for instance, will enable Beijing to enter this strategic business and spread propaganda that serves its interests. ${ }^{(21)}$ Others worry that trading with China will fundamentally change the Taiwanese way of life. Liu Shao-hua, an anthropologist at the Academia Sinica, puts forward such a viewpoint in her widely circulated article. She argues that the values that stand behind the incoming Chinese capital - including party-state hege- mony, monopoly of big Chinese firms, government suppression against civic freedom, and the lack of respect for human dignity - constitute a palpable threat to Taiwanese values, which are centred on individual freedom. ${ }^{(22)}$

Parallels with China's economic integration strategy can in fact be more explicitly found in the context of Hong Kong under the implementation of CEPA. While opponents of the Taiwanese service trade pact have pointed to the widening of poverty gap in Hong Kong over the past decade, these references have overlooked the equally significant aspect of CEPA regarding economic dependence. Official statistics in Hong Kong have shown the rising dependence of the economy on China. Over the past decade, Hong Kong's trade volume with China has increased three-fold (Graph 1), and is steadily growing as a percentage of its total trade (Graph 2). Inward direct investment from China and outward direct investment to China, compared with other countries, have also risen significantly in terms of proportion. Meanwhile, under the Individual Visit Scheme (IVS) as part of CEPA, Hong Kong has witnessed a rapid increase in Chinese tourists visiting the territory (Graph 3). The number of Chinese tourists as a percentage of total incoming visitors rose steadily, reaching $75 \%$ in 2013 (Graph 3). In a recent government report assessing Hong Kong's capacity to receive tourists, it was estimated that annual tourists to Hong Kong could further rise to 70 million in 2017 and 100 million in 2023, with the majority of them expected to be from China. ${ }^{(23)}$ In short, as academic Sonny Lo noted, "Hong Kong has transformed from 'a

18. Ibid.

19. Ibid.

20. Szu-chien Hsu, "Weihe buneng dui fangjian li de daxiang zhuang ke'ai? Zhonggong dangguo ziben zhuyi yu fumao" (Why can't we act cute towards the elephant in the room? China's party-state capitalism and (SSTA), United News, 20 March 2014, available at http://mag.udn.com/mag/ news/storypage.jsp?f_ART_ID=504926 (accessed on 22 April 2014).

21. Rex How, "Wo kanjian de yu wo xiangxin de" (What I see and what I believe), 10 July 2013, available at http://opinion.cw.com.tw/blog/profile/88/article/469 (accessed on 24 April 2014).

22. Shao-hua Liu, "Cong zhongguo de fazhan laitan fumao qiandong de jiazhi wenti" (Discussing the values underlying the CSSTA from China's development), 27 March 2014, available at www.thinkingtaiwan.com/articles/view/1892 (accessed on 22 April 2014).

23. "Assessment Report on Hong Kong's Capacity to Receive Tourists," Hong Kong Board of Tourism, December 2013, available at www.tourism.gov.hk/resources/english/paperreport_doc/misc/201401-17/Assessment_Report_eng.pdf (accessed on 22 April 2014). 
Graph 2 - Hong Kong and Taiwan's Proportion of Trade with mainland China
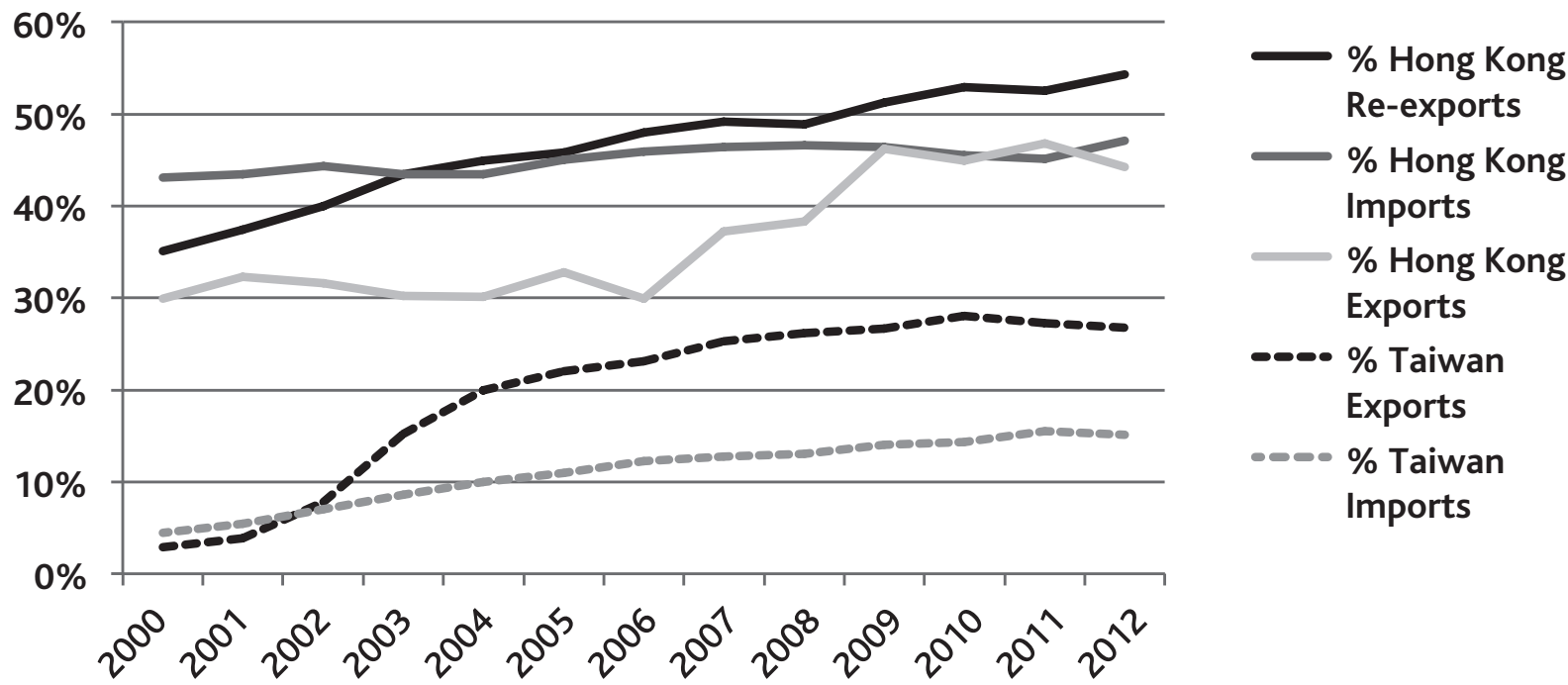

Source: Hong Kong Census and Statistics Department, Taiwan's Ministry of Finance.

core' shaping the development of peripheral China into a region more dependence on the mainland's economic support than ever before." (24)

In recent years, closer economic partnership between China and Hong Kong has proceeded toward active takeover of Hong Kong companies by Chinese companies. In January 2014, State Grid Corporation of China, the largest state-owned electric utility, purchased an $18 \%$ stake in Hong Kong Electric and became the second largest shareholder in this sole electricity provider on Hong Kong Island. This seems to be consistent with the suggestion of Li Jinying, manager of the state-owned China Resources Power, to the Hong Kong Chief Executive Office during his visit with a business delegation in 2013. Li recommended that the Hong Kong government resume control over the two electric companies, CLP Power and Hong Kong Electric, and hand them over to Chinese companies. ${ }^{(25)}$ Another manager, Tan Xinjian, even urged Chinese companies to simply buy out the two electric giants. (26)

While the standalone effect of CEPA on Hong Kong's increased dependence on China might be difficult to quantify, and while researchers have begun to question the often claimed economic benefits, (27) what is more certain is that the dependence that CEPA induces has provided an open platform for the CCP to carry out united front work in Hong Kong, which allows Beijing to co-opt elites to advance its political interests - a dynamic that fuelled the worries of Taiwanese protesters. While the CCP's united front work has a long history in Hong Kong, it has mostly been kept secretive and underground. (28) Even after China resumed sovereignty over Hong Kong in 1997, Beijing's political intervention remained discreet, as "One Country Two Systems" has barred Beijing from openly intervening in Hong Kong's internal affairs. The introduction of CEPA, however, provides an open and legitimate platform for united front work. As Ke Dai, an official at the United Front Department of Guangzhou's Sun Yat-sen University, wrote, "CEPA allows China to use economics as an axis to strengthen political communication between both sides and speed up the return of Hong Kong people's hearts (renxin huigui人心回歸)." (29)

To promote political ties, Ke urged the United Front Department to strengthen communication with professionals, trade associations, chambers of commerce, and NGOs in Hong Kong. In fact, the suggestion to increase
mainland-Hong Kong business ties under CEPA has already become a regular practice. Over the past decade, Hong Kong business groups have made frequent visits to Chinese cities at the invitation of local governments and the United Front Work Department. ${ }^{\left({ }^{30}\right)}$ Reciprocal visits by Chinese political and business groups have also been frequent and often involve high-level party officials. Most notably, Chinese President Xi Jinping led a delegation of over 650 government officials and businessmen to Hong Kong in January 2005 while serving as the Party secretary of Zhejiang. ${ }^{\left({ }^{311}\right)}$ The event, named "Zhejiang Week," reached an agreement on 153 Zhejiang-Hong Kong projects under CEPA totalling USD2.4 billion. ${ }^{(32)}$

24. Sonny Shiu-Hing Lo, The dynamics of Beijing-Hong Kong relations: A model for Taiwan?, Hong Kong, Hong Kong University Press, 2008, p. 65.

25. "Huarun gaoceng chang zhongzi jieguan liangdian" (High-ranking managers of China Resources Company proposed Chinese companies to take over the two Hong Kong electric companies), Ming Pao News, 17 March 2014, available at www.mpfinance.com/htm/finance/20140 317/News/ea_eaa1.htm (accessed on 22 April 2014).

26. Ibid.

27. Tai-lok Lui, "Fading Opportunities: Hong Kong in the context of regional integration," China Perspectives, No. 2014/1, pp. 35-42.

28. Yaoru lin, Zhong gong Xianggang zheng ce mi wen shi lu: lin Yaoru wu shi nian Xiangjiang yi wang (CCP's Hong Kong Policies: Jin Yaoru's Memoir of 50 Years by the Fragrant River), Kowloon, Hong Kong, Tian yuan shu wu, 1998; Cindy Yik-yi Chu, Chinese Communists and Hong Kong Capitalists: 1937-1997, New York, Palgrave Macmillan, 2010; Christine Loh, Underground Front:The Chinese Communist Party in Hong Kong, Hong Kong, Hong Kong University Press, 2010; Kwan Sang Kiang, Zhonggong zai Xianggang (CCP in Hong Kong), Hong Kong, Cosmos Books, 2011 (part 1), 2012 (part 2).

29. Dai Ke andYu Du, "Lun CEPA dui Xianggang shehui zhenshi de jiji yingxiang ji ruhe zuohao xiangying de tongzhan gongzuo" (Discuss the positive impact of CEPA on Hong Kong's politics and society and how to carry out united front work), Gang Ao haiwai tongzhan gongzuo xintansuo (New Exploration on United Front Work in Hong Kong and Macau), 2008; the quote is my own translation.

30. Hong Kong business delegations to China are often received by local governments and local United Front Work Department representatives. See for example: "HKCCC's International Character Can Help Mainland Enterprises Go Global," Hong Kong General Chamber of Commerce, 5 November 2013, available at www.chamber.org.hk/en/media/press-releases_detail.aspx?ID=3503 (accessed on April 27, 2014)

31. "2005 xianggang zhejiang zhou jijiang zaigang juxing" (2005 Hong Kong's Zhejiang Week is going to take place soon), People's Net, January 14, 2005, available at http://people.com.cn/BIG5/ 42272/42273/3121082.html (accessed on 22 April 2014).

32. "Shoupo zhongbang ji xiangmu jiang qianyue" (The first batch of major projects will be signed) People's Net, 17 January 2005, available at http://politics.people.com.cn/BIG5/1025/ 3124848.html (accessed on 22 April 2014) 


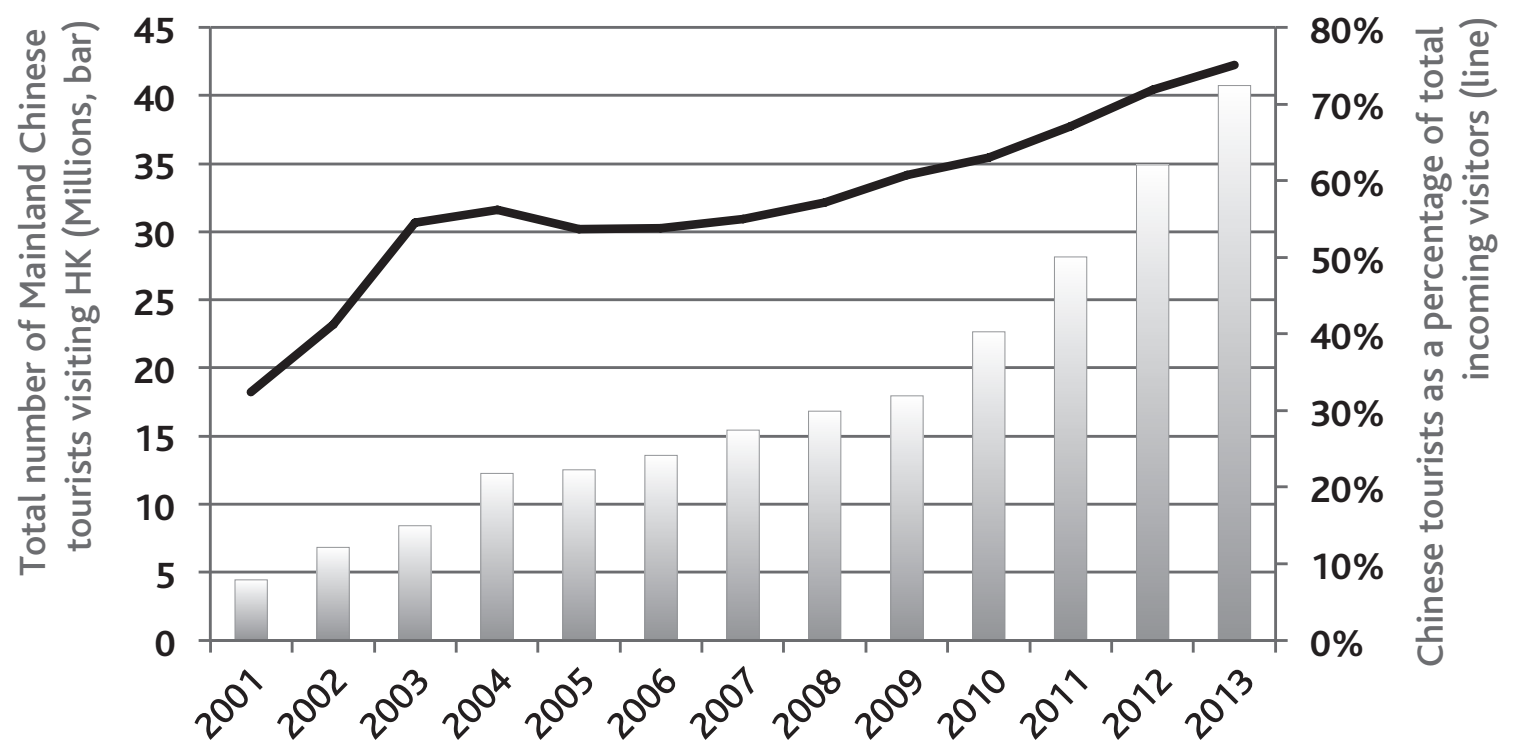

Source: Hong Kong Census and Statistics Department.

Examples such as these are plentiful but await more systematic documentation. More recently, however, scholars have started to research China's latest united front strategies in Hong Kong. Brian C. Fong, for example, labelled the strategies as "the partnership between the Chinese government and Hong Kong's capitalist class." He observes that Hong Kong business elites have been increasingly over-represented among the Hong Kong delegations to the National People's Congress and the Chinese People's Political Consultative Conference. He argues that excessive representation allows them to establish direct and institutionalised access to the sovereign state. This kind of circumvention, according to Fong, has "undermined the relative autonomy of the post-colonial state and resulted in growing cleavages within the state-business alliance." (33) The formation of such an interest group also shows striking similarities to the effects of the KMT-CCP forum in Taiwan.

Despite the practice of keeping motives discreet, China's use of economic integration to exert political influence in both Hong Kong and Taiwan has been "leaked" by Chinese state media. Global Times, a hawkish CCP mouthpiece, published a translated article in February 2014, entitled "Beijing's Strategy to 'buy' Taiwan: Coerced Unification Without Firing a Shot," (34) which was originally written by Parris Chang, a US-based Taiwanese scholar, on the World Tribune. ${ }^{(35)}$ Chang's critical undertone against Beijing's political advance on Taiwan contrasted bizarrely with Global Times' decision to translate the article into Chinese. The article argues that Beijing seeks to advance cross-strait integration through the service trade agreement. "From Beijing's perspective," it argues, "this agreement is intended also to perform vital political and united front functions in Taiwan." It then adds the comparison between Hong Kong and Taiwan:

"As shown by the experience of Hong Kong, the agreement will provide legal cover for China's agents to live and work throughout Taiwan. Through Chinese enterprises and shops, China's operatives would continue to build up its resources, and strengthen its capability to influence and shape Taiwan's political process and policy efforts toward peaceful unification without firing a shot." (36)
It is unclear whether the Global Times published this article (despite its critical tone) because it naively endorses the strategy denounced by Chang, but at the very least, we may surmise that such a strategy is being increasingly discussed in Beijing.

\section{China's new attitude towards Hong Kong and Taiwan?}

Although the appearance of a single article in the Global Times does not necessarily reflect Beijing's official position, a much more authoritative source may have testified to China's new attitude towards Hong Kong and Taiwan. In Premier Li Keqiang's first annual work report delivered to the National People's Congress in March 2014, there were significant changes in the sections regarding Hong Kong and Taiwan. ${ }^{\left({ }^{37}\right)}$ Compared to the reports delivered in previous years, the two sections were almost tripled in length, and the wording Premier Li used was different from that chosen by former Premier Wen Jiabao. When speaking about Hong Kong, the default statement of "the people of Hong Kong governing Hong Kong" (Gang ren zhi Gang 港人治港) and "high degree of autonomy" (gaodu zizhi 高度自治) were removed for the first time in ten years. (38) Only "One Country Two

33. Brian C. H. Fong, "The Partnership between the Chinese Government and Hong Kong's Capitalist Class: Implications for HKSAR Governance, 1997-2012," The China Quarterly, Vol. 217, 2014, pp. 195-220.

34. "Meimei: Beijing huo bufa yiqiang 'maixia' taiwan" (US media: Beijing might 'acquire' Taiwan without firing a shot), Global Times, 21 February 2014, available at http://oversea.huanqiu.com/political/2014-02/4848415.html (accessed on 22 April 2014).

35. Parris H.Chang, "Beijing's Strategy to Buy Taiwan: Coerced unification without firing a shot," World Tribune, 19 February 2014, available at www.worldtribune.com/2014/02/19/beijings-strategyto-buy-taiwan-coerced-unification-without-firing-a-shot/ (accessed on 22 April 2014)

36. Ibid.

37. China's Government Work Report 2014, available at http://news.sina.com.cn/c/2014-0314/183329709929.shtml (accessed on 22 April 2014).

38. When asked by Hong Kong media about the removal of the line, Chinese officials explained that it was for the sake of saving words. See "Li Keqiang baogao buti xianggang 'gaoduzizhi' yin caice" (Speculation abounds as Li Keqiang did not mention high degree of autonomy), BBC News Chinese, 6 March 2014, available at www.bbc.co.uk/zhongwen/trad/china/2014/03/140306_ china_npc_hongkong.shtml (accessed on 22 April 2014). 
Systems" was kept in the section, with an added emphasis on "fully and correctly implement the Basic Law" (quanmian zhunque luoshi jibenfa 全面準 確落實基本法). The statement then urged "further increasing cooperation between the mainland and both Hong Kong and Macau" so as to "enhance their competitiveness," adding that both regions will benefit as the mainland deepens reform comprehensively and modernises.

In the section about Taiwan, the differences are even more striking. Beijing will now "fully implement" (quanmian guanche 全面貫徹), as opposed to merely "adhering to" (jianchi 堅持), the major policies concerning Taiwan affairs. Moreover, what used to be a generic description of these policies is now substantiated by a number of principles. This includes upholding the 1992 Consensus under the one-China framework, strengthening crossstraits political trust, promoting economic integration, exchanges and cooperation, and engaging in consultations and negotiations. The underlying principle is now made explicitly poignant. Grounded on the vision that "people on both sides of the straits are one family" (liangan yijia qin 兩岸一家 親), China will "uphold our kindred friendship and work together with our compatriots to build the beautiful homeland of the Chinese nation and achieve China's peaceful reunification." This direction, it concluded, will become an "irresistible and irreversible trend in history."

While the strategy itself was nothing new, as has been evident under the CCP's increasing contact with the KMT in the Hu jintao era and gradual inclusion of Hong Kong into China's economic development over the past years, the substantial revision of such a high-level policy blueprint reflects the rationalisation of the CCP's strategies towards both regions under the new administration of Xi Jinping and Li Keqiang. Although the differences between the respective sections on Hong Kong and Taiwan are meant to acknowledge their distinct political relationships with China, they are nevertheless strikingly coherent in their emphasis on fostering political ties through economic exchange, cooperation, and integration. Beijing's ultimate objective of bringing about reunification appeared even more tangible during a meeting between President Xi Jinping and Lien Chan in February 2014, in which Xi introduced his "three-stage formula" for enhancing cross-strait ties. According to the formula, cross-strait communication will now move from the first stage, which focuses on economic and non-political exchanges, to the second stage, which develops official contacts or meetings between the two sides' government heads, proceeding finally to full crossstraits political talks on an "equal basis" to discuss "peaceful reunification." (39) Seen in this light, just as economic integration in Hong Kong has helped to strengthen China's political control over the territory, economic integration in Taiwan serves as a basis for promoting institutionalised political discussions between the CCP and KMT. Both Hong Kong's CEPA and Taiwan's ECFA (together with CSSTA) can thus be seen as tools to advance Beijing's policies. The dormant model of "One Country Two Systems," which was said to be a formula devised for reunifying Taiwan based on the promise of political autonomy, seems to be quietly revived through the promotion of economic integration.

\section{Political resistances against China in Taiwan and Hong Kong}

The acceleration of China's political advance in Taiwan and Hong Kong has led to worrying repercussions in both societies, which are especially noticeable in the media realm. According to the World Press Freedom Index 2014 released by Reporters without Borders, Taiwan's ranking fell three notches from a year earlier to $50^{\text {th }}$ place. The report mentioned "pro-Beijing Want Want group's acquisition of the China Times" as a threat to Taiwan's media freedom, referring to "China's growing economic weight" as an enabler to extend influence over the media in Hong Kong, Macau, and Taiwan, "which had been largely spared political censorship until recently." (40) Similar press censorship, probably even more blatant, has been taking place in Hong Kong. The same index showed that Hong Kong's ranking has tumbled from $18^{\text {th }}$ in 2002 to $61^{\text {st }}$ in 2013. A Wall Street Journal report released in February 2014, which highlighted the simultaneous erosion of press freedom in Taiwan and Hong Kong, quoted another recent report by the Committee to Protect Journalists that focused on Hong Kong's increasing trend toward self-censorship as well as frequent attacks targeting journalists and outspoken media outlets. ${ }^{(41)}$ Not long after the report was released, Kevin Lau, the former chief editor of the influential and critical newspaper Ming Pao, was violently attacked by two hit men. While the motive remains unclear, the attack was widely suspected to have connections with the newspaper's collaboration with the International Consortium of Investigative Journalists (ICIJ) on a project about offshore money leaks, in which connections to families of high Chinese officials have been uncovered. ${ }^{(42)}$

In Taiwan, worries over Beijing's ulterior motives have loomed over society for the past few years, triggering protests such as the anti-media monopoly movement in 2012, in which people protested against an attempt by the pro-China Want Want China Times Media Group to expand its media empire. ${ }^{(43)}$ Although protesters failed to stop its forceful acquisition of the China Network Systems, the pressure did contribute to preventing Want Want from acquiring Taiwan's Apple Daily, a critical newspaper held by Hong Kong media tycoon Jimmy Lai. ${ }^{(44)}$ Meanwhile, sporadic protests against signing the ECFA with China have fermented since 2010. At that time, protesters already worried that the framework agreement would increase China's influence over Taiwan, and would be "tantamount to a first step toward unification" - a concern especially amplified as Taiwan approached the 2012 presidential election. ${ }^{45}$ ) The Sunflower Student Movement that erupted in March 2014 can thus be seen as the culmination of periodic protests over the past several years.

Apart from being much larger in scale, what distinguishes the movement from previous protests, as media commentator Chang Tieh-chih pointed out, is that it brought the China factor out into the public limelight for wider discussion. (46) Previously, although awareness of the China factor has long existed in Taiwan, it was largely circumscribed and did not gain traction in the broader Taiwanese society, most likely due to the tense polarisation between advocates of unification and independence. During the Sunflower

39. "Cujin heping fazhan shixian heping tongyi" (Promote peaceful development, materialise peaceful reunification), Guangming Daily, 22 April 2014.

40. World Press Freedom Index 2014, Reporters Without Borders, available at http://rsf.org/ index2014/en-index2014.php (accessed on 24 April 2014).

41. "Hong Kong, Taiwan's Eroding Freedom of Press," The Wall Street Journal, 13 February 2014.

42. Samson Yuen and Kitty Ho, "Hong Kong: Two Systems, One Country?", The Diplomat, 8 March 2014, http://thediplomat.com/2014/03/hong-kong-two-systems-one-country/ (accessed on 30 April 2014).

43. Mark Harrison, "The Anti-Media Monopoly Movement in Taiwan," The China Story, 20 December 2012.

44. Gerry Mullany, "As Media Deal in Taiwan Collapses, Political Fallout Lingers," The New York Times, 27 March 2013.

45. Vincent Y. Chao and Rich Chang, "Approaching ECFA: Protesters brave storms to rally against ECFA," Taipei Times, 27 June 2010.

46. Tieh-chih Chang, "Taiwan de shidai geming" (Taiwan's generational revolution), Ming Pao, 2 April 2014. 
Movement, one distinctive feature was the vibrant discussions and circulation of articles that drew attention to the China factor. As opposed to rejecting China outright, authors typically spoke of the necessity to engage with China apart from being aware of its influence. For example, in Liu Shaohua's piece, despite warning against the potential value clash brought by China, she said, "We don't need to demonise China... and we cannot refuse to engage with China because China is our neighbour." (47) For these authors, the unification/independence dichotomy is out-dated. Engaging with China is neither to utterly reject nor to unreservedly embrace by giving up Taiwanese identity. It is rather to understand the mechanism through which China influences Taiwan, to discuss the extent and the boundary of future engagement, and to deliberate upon the institutional arrangement of crossstraits interaction. That was why protesters insisted that they were not against the service trade pact in principle, and even admitted that some form of engagement with China is inevitable. What they demanded was an oversight mechanism that could monitor future cross-straits negotiation, and only after that could the service trade pact return to the legislating agenda. Ma's promise to implement such a mechanism, and thus to bring the entire Cross-Straits dynamics back under democratic control, undeniably represents a significant achievement of the Sunflower Movement.

This acknowledgement of China, according to J. Michael Cole, also signifies the emergence of a new Taiwanese identity that appeals to the majority of Taiwanese. As he writes,

It does not oppose trade deals, nor does it reject cultivating good relations with China. But it has drawn lines with regards to the ways of life and freedoms of all Taiwanese and sent a clear warning that anyone who crosses those lines will face a challenge from thousands of highly educated, connected, and united Taiwanese. ${ }^{(48)}$

In Hong Kong, looming economic integration with mainland China has sparked increasing political resistances in recent years. The 2010 protest against the plan to build a costly express rail link between Guangzhou and Hong Kong kicked off a public debate about the need to integrate into the Pearl River Delta regional economic zone. Although the protest failed to stop the plan, it sparked a wider discussion regarding the drawbacks of closer economic integration with mainland China. Many began to be aware of the increasing dependence of the economy on China and its overlooked disadvantages. Grassroots NGOs, such as the Local Research Community (bentu yanjiu she 本土研究社) and the Land Justice League (tudi zhengyi lianmeng 土地正義聯盟), were formed with the objective to study the impact of regional integration and urban redevelopment on the local economy, to produce local knowledge to resist the government's grand narrative. ${ }^{(49)}$ More crucially, these local NGOs have played the role of monitoring the government over integration plans - similar to the way Taiwanese protesters demanded an oversight mechanism to monitor cross-strait negotiations. For instance, they drew attention to the one-sided inclusion of Hong Kong into China's state planning, namely the $12^{\text {th }}$ Five-Year Plan (2011-2015) and Outline of the Program for Reform and Development of the Pearl River Delta (2008-2020), in the absence of domestic democratic consent, and protested against the remaking of the New Territories to support the development of Qianhai, a district in Shenzhen, into a new retail hub. ${ }^{(50)}$

Others emphasise the need to preserve the local identity and way of life under economic integration with China, taking issue particularly with the influx of mainland tourists as a convenient target for resistance. Tensions began to erupt in early 2012 as a luxury brand allegedly banned locals from taking photographs outside its flagship store, appearing to favour wealthy Chinese tourists. Staging regular protests against mainland visitors since then, angry Hongkongers described them as "locusts" for their perceived "uncivilised" behaviour and their purchase of local resources such as pharmaceuticals and baby formula. Combined with the anti-national education campaign in 2012, these tensions have coalesced into an emerging phenomenon of "de-Sinicisation" (qu Zhongguohua 去中國化) and renewed discussions about the local identity. ${ }^{(51)}$ One representative view was put forth by Chin Wan-kan, the author of the award-winning book Hong Kong as a City-state (XiangGang chengbang lun 香港城邦論). Chin advocated the autonomy of Hong Kong as a city-state, which is distinguished by unique and superior features such as its Cantonese-speaking population, traditional Chinese characters, and its preservation of the Cantonese culture. In order to protect Hong Kong's autonomy, people should focus solely on local affairs and exclude all things mainland Chinese, even the frequent human rights abuses and June 4th commemoration. Since then, the term "nativists" or "localists" (bentupai 本土派) has emerged in the local political lexicon to draw a distinction from those whom Chin denigrates as the "Greater China

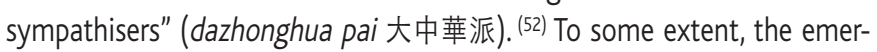
gence of "nativism" in Hong Kong harks back to Taiwan's democratisation during the 1980s, where the strengthening and politicisation of local Taiwanese identity played a crucial role. Whether such a force will be an impetus for democratisation in Hong Kong is something to be closely watched. On the other hand, the bifurcated strategies of political resistance in Hong Kong - one is to monitor and check Chinese influence, the other to utterly reject China in spite of China's strong presence - suggest an interesting comparison with the gradual acceptance of the need to engage with China, albeit with caution, in Taiwan. Why that is the case, however, also awaits further inquiry. Another new feature of this resistance against China's advance is the growing links between the civil societies of Hong Kong and Taiwan. In late 2013, the organisers of Hong Kong's budding pro-democracy campaign, Occupy Central (zhanling zhonghuan 佔領中環), travelled to Taiwan to give public talks about the electoral reform movement in the hope of borrowing insights from Taiwan's social movements. ${ }^{\left({ }^{3} 3\right)}$ Earlier this year, a two-day forum bringing together social activists from Taiwan and Hong Kong was held in Taipei, aiming to explore the possibility of more frequent civil society collaboration. The opportunity to collaborate soon materialised through the Sunflower Movement. During the Movement, Taiwanese protesters repeatedly referred to the lesson of Hong Kong under CEPA as ground to reject signing the CSSTA. Meanwhile, many in Hong Kong voiced support for the Taiwan protests. A group of Hongkongers placed an advertisement

47. Liu Shao-hua, "Cong zhongguo de fazhan laitan fumao qiandong de jiazhi wenti" (Discussing the values underlying the CSSTA from China's development).

48. J. Michael Cole, "Sunflowers End Occupation of Taiwan's Legislature," The Diplomat, 11 April 2014, available at http://thediplomat.com/2014/04/sunflowers-end-occupation-of-taiwans-legislature/ (accessed on 22 April 2014)

49. Website of the Local Research Community, available at http://localresearchcommunity. wordpress.com/ (accessed on 22 April 2014); website of the Land Justice League is available at http://landjusticehk.org/ (accessed on 22 April 2014).

50. Kim Ching Chan, "Zhonggang shuangcheng qimou: Xinjie dongbei jihua de qianshi jinsheng" (A strange tale of two cities: The past and present of the plan on the Northeast), Inmedia HK, 5 July 2013, available at www.inmediahk.net/node/1017197 (accessed on 27 April 2014).

51. Karita Kan, "Lessons in Patriotism: Producing National Subjects and the De-Sinicisation Debate in China's post-colonial city," China Perspectives, No. 2012/4, pp. 63-70.

52. "Independent thinker Horace Chin treads bold path," South China Morning Post, 10 June 2013.

53. "Pro-democracy and Occupy Central leaders travel to Taiwan to share ideas," South China Morning Post, 19 October 2013. 
in Liberty Times, a Taiwan newspaper, urging Taiwan protesters to learn the painful lesson of Hong Kong. ${ }^{(54)}$ On March 26, a protest was held by university students in Hong Kong to support the Taipei sit-in. ${ }^{(55)}$ In addition, two public forums were held by civic groups in Hong Kong to discuss the implications of the Taiwan protests in connection with Hong Kong, one of which was convened by the Local Research Community as an inauguration to kick off a research project on CEPA. (56) Perhaps most striking of all, Lin Feifan, student leader of the Sunflower Movement, was spotted wearing a black "Occupy Central" T-shirt during the protesters' retreat from the legislature. Although the fashion choice was likely unintentional, Lin later said in an interview that he was inspired by the element of deliberative democracy proposed by the Hong Kong movement. ${ }^{(57)}$

\section{Conclusion}

While Beijing's strategy of co-opting political and business elites in both Hong Kong and Taiwan through economic integration is maturing and is paying off to some extent, political resistance in both territories continues to develop and has managed to constrain at least some of Beijing's advances. In Taiwan, increasingly frustrated at the submissiveness of politicians and business elites towards China, the younger generation is demanding more transparency and accountability in the process of crossstraits negotiations, which they insist should be predicated on the island's preservation as an independent political entity. In Hong Kong, local identity has become a nascent political force. Despite the government agenda to promote Chinese national identity and patriotism, Hong Kong people are increasingly identifying themselves as "Hongkongers" rather than "Chinese." (58) Fierce resistance against clandestine integration plans, patriotic propaganda, and the influx of mainland tourists only serves to further de-Sinicise Hong Kong and strengthen the budding nativist identity. As links between the civil societies of Taiwan and Hong Kong continue to develop in parallel, it will not be surprising to see more collective resistance from both territories against the political threat from China in the near future.

I Samson Yuen is a PhD student in politics at the University of Oxford and is a research assistant at the CEFC (Samson.yuen@sant.ox.ac.uk).

CEFC News Analysis is compiled from the CEFC's fortnightly selection of Press Highlights, available at www.cef.com.hk.

54. "Shubai gangren jizi zai taibao deng guanggao zhichi xuesheng fan fumao xieyi" (Hundreds of Hong Kongers donate to place advertisement on Taiwan newspaper supporting the anti-CSSTA movement), RFI, 28 March 2014, available at www.chinese.rfi.fr/\%E4\%B8\%AD\% E5\%9B\%BD/20140328\%E6\%B8\%AF\%E4\%BA\%BA\%E5\%9C\%A8\%E5\%8F\%B0\%E6\%8A\%A5\%E 7\%99\%BB\%E5\%B9\%BF\%E5\%91\%8A\%E6\%94\%AF\%E6\%8C\%81\%E5\%AD\%A6\%E7\%94\%9F\% E5\%8F\%8D\%E6\%9C\%8D\%E8\%B4\%B8\%E5\%8D\%8F\%E8\%AE\%AE (accessed on 22 April 2014).

55. "Hong Kong students join Taiwan sit-in," South China Morning Post, 27 March 2014.

56. Sin Yum Lam, "Huigu heixiang CEPA shinian" (Reviewing CEPA, the ten-year black box), InmediaHK, 9 April 2014, available at www.inmediahk.net/2014040905 (accessed on 24 April 2014).

57. "Zhanling yundong dangren burang" (To occupy is to do one's moral duty), House News, 18 April 2014, available at http://thehousenews.com/佔中專訊/佔領運動-當仁不讓-專訪台灣學運領 袖林飛帆-施懿倫/(accessed on 24 April 2014).

58. Sebastian Veg, "Hong Kong's enduring identity crisis," The Atlantic, 16 October 2013, available at www.theatlantic.com/china/archive/2013/10/hong-kongs-enduring-identity-crisis/280622/ (accessed on 22 April 2014). 